\title{
Hydrosilylation Polymerization for the Synthesis of Organosilicon Polymers Containing Adamantane Units
}

\author{
By Takayuki Maehara, Joji OHShita, ${ }^{*}$ Ryo TAKETSUGU, Koichi Hino, and Atsutaka KunaI
}

\begin{abstract}
Hydrosilylation of diethynylbenzene with bis(dihexylsilylpropoxy)-, bis(diphenylsilylpropoxy)-, and bis(methylphenylsiloxy)adamantane (1a, 1b, and 1c) afforded the corresponding hydrosilylated polymers. A similar reaction of bis(allyloxy)adamantane with $\mathbf{1 b}$ also gave a polymer with repeating units of Ad-propylene-silanylene-propylene (Ad = adamantanediyl). Heat-resistance of the resulting polymers was examined by the thermogravimetric analysis and the highest $T_{\mathrm{d}_{5}}$ and $T_{\mathrm{d}_{10}}$ (temperatures of 5 and $10 \%$ weight loss) among the present polymers were noted to be $370{ }^{\circ} \mathrm{C}$ and $393{ }^{\circ} \mathrm{C}$, respectively, for the polymer prepared from the reaction of diethynylbenzene with 1c. Cross-linking hydrosilylation of a vinylsiloxane polymer with 1c was also studied.

KEY WORDS: Adamantane / Organosilicon Polymer / Siloxane / Hydrosilylation / Heat-Resistance /
\end{abstract}

There has been interest in the synthesis of adamantane unit-containing polymers. The cage structure of adamantane allows their application as heat-resistance materials and polymers containing adamantane units as the side, ${ }^{1}$ backbone, ${ }^{2-4}$ and end-capping groups ${ }^{5}$ have been reported so far. Adamantane-based epoxy resins were also reported regarding their use as encapsulants for light-emitting diode (LED). ${ }^{6}$ For the polymers with adamantane units in the backbone, poly(adamantanediyl)s were recently prepared by ring-opening polymerization of dehydroadamantane, whose thermogravimetric analysis (TGA) showed high heat-resistance properties with $T_{\mathrm{d}_{10}}$ (10\% weight loss temperatures) of $421^{\circ} \mathrm{C}$ and $486^{\circ} \mathrm{C}$ in nitrogen for $\mathrm{R}=\mathrm{H}$ and $\mathrm{Bu}$, respectively (Scheme 1). ${ }^{2}$ Copolymers of dehydroadamantane and vinyl compounds (AN and MA), ${ }^{3}$ and adamantane unit-containing polyimides $^{4}$ shown in Scheme 1 were also synthesized and their heat-resistance was reported.

To obtain novel adamantane-based polymers, we prepared polymers composed of repeating units of -Ad-O-Si-O- by dehydrocoupling of adamantanediol and $\mathrm{PhSiH}_{3}$ (Scheme 1) and found that these polymers showed higher $T_{\mathrm{d}_{10}}$ of $512{ }^{\circ} \mathrm{C}$ in nitrogen than poly(adamantanediyl)s. ${ }^{7}$ However, the polymers contained $\mathrm{Si}-\mathrm{OH}$ bonds, arising from hydrolysis of the $\mathrm{Si}-\mathrm{H}$ groups, which may cause disadvantages when applied to insulating films and encapsulation materials for electronic devices. For example, the $\mathrm{Si}-\mathrm{OH}$ units may decrease the electric resistance of the polymer film and their condensation librating water may cause the aging deterioration. In the hope of obtaining heat-resistant adamantane unit-containing organosilicon polymers without $\mathrm{SiOH}$ units, we studied hydrosilylation polymerization of diethynylbenzene and bis(allyloxy)adamantane with bis(hydrosilyl)-substituted adamantane derivatives. An application of bis(methylphenylsiloxy)adamantane prepared by dehydrocoupling of adamantanediol and $\mathrm{PhMeSiH}_{2}$, as a cross-linking reagent was also examined.
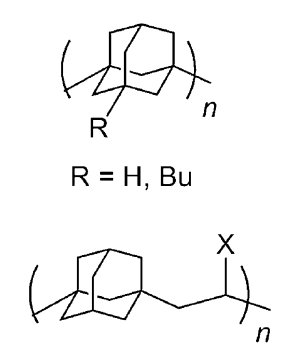

$\mathrm{X}=\mathrm{CN}, \mathrm{CO}_{2} \mathrm{Me}$

Scheme 1. Heat-resistant polymers with adamantane units in the backbone.

\section{EXPERIMENTAL}

\section{General Procedure}

All reactions were carried out in dry nitrogen. Toluene used as the reaction solvent was distilled from sodium and stored over activated molecular sieves at ambient temperature until use. Bis(allyloxy)adamantane ${ }^{6 \mathrm{~b}}$ and bis(methylphenylsiloxy)adamantane $(\mathbf{1 c})^{7}$ was prepared as reported in the literature.

\section{Preparation of Bis(hydrosilylpropoxy)adamantanes}

A solution of $0.82 \mathrm{~g}(3.3 \mathrm{mmol})$ of bis(allyloxy)adamantane, $1.38 \mathrm{~g}(6.91 \mathrm{mmol})$ of dihexylsilane, and $4.6 \mathrm{mg}(0.0049 \mathrm{mmol})$ of $\mathrm{RhCl}\left(\mathrm{PPh}_{3}\right)_{3}$ in $10 \mathrm{~mL}$ of toluene was stirred at room temperature for $3 \mathrm{~h}$. The resulting mixture was directly subjected to silica gel column chromatography eluting with toluene to give $1.77 \mathrm{~g}$ ( $82 \%$ yield) of bis(dihexylsilylpropoxy)adamantane (1a) as colorless oil: IR $2097 \mathrm{~cm}^{-1}(\mathrm{Si}-\mathrm{H})$; ${ }^{1} \mathrm{H} \mathrm{NMR} \mathrm{(} \delta$ in $\left.\mathrm{CDCl}_{3}\right) \quad 0.51-0.59\left(\mathrm{~m}, \mathrm{SiCH}_{2}\right), 0.86 \quad(\mathrm{t}$, $\left.J=7.0 \mathrm{~Hz}, \mathrm{CH}_{3}\right), 1.23-1.29\left(\mathrm{~m}, \mathrm{SiCH}_{2}\left(\underline{\mathrm{CH}}_{2}\right)_{4} \mathrm{CH}_{3}\right), 1.47-$ $1.74\left(\mathrm{~m}, \mathrm{Ad}\right.$ and $\left.\mathrm{OCH}_{2} \underline{\mathrm{CH}}_{2}\right), 2.28\left(\mathrm{~s}, \mathrm{Ad} \mathrm{OCCH}{ }_{2} \mathrm{CO}\right), 3.34(\mathrm{t}$, $\left.J=7.0 \mathrm{~Hz}, \mathrm{OCH}_{2}\right), 3.66$ (quint, $\left.J=3.1 \mathrm{~Hz}, \mathrm{SiH}\right) ;{ }^{13} \mathrm{C} \mathrm{NMR}(\delta$ 
in $\left.\left.\mathrm{CDCl}_{3}\right) 7.44\left(\mathrm{O}_{\left(\mathrm{CH}_{2}\right.}\right)_{2} \mathrm{CH}_{2}\right), 11.24,14.12,22.59,24.59$ (Hex), $25.84\left(\mathrm{OCH}_{2} \mathrm{CH}_{2}\right), 31.56,33.03$ (Hex), 30.80, 35.49, 40.73, 45.52 (Ad CH and $\mathrm{CH}_{2}$ ), $63.06\left(\mathrm{OCH}_{2}\right), 74.09$ (Ad q-C); Anal. Calcd for $\mathrm{C}_{40} \mathrm{H}_{80} \mathrm{O}_{2} \mathrm{Si}_{2}$ : C, 74.00; H, 12.42. Found: C, 73.70; H, 12.43 .

Bis(diphenylsilylpropoxy)adamantane (1b) was obtained in $87 \%$ yield in a manner similar to that above, using diphenylsilane instead of dihexylsilane as the reactant: colorless oil; IR $2116 \mathrm{~cm}^{-1}(\mathrm{Si}-\mathrm{H}) ;{ }^{1} \mathrm{H}$ NMR $\left(\delta\right.$ in $\left.\mathrm{CDCl}_{3}\right) 1.09-1.15(\mathrm{~m}$, $\mathrm{CH}_{2} \mathrm{Si}$ ), 1.44-1.71 (m, Ad and $\mathrm{OCH}_{2} \underline{\mathrm{CH}}_{2}$ ), 2.24 (s, Ad $\mathrm{OCCH}_{2} \mathrm{CO}$ ), 3.35 (t, $J=6.7 \mathrm{~Hz}, \mathrm{OCH}_{2} \mathrm{CH}_{2}, 4.84$ (t, $J=3.6$ $\mathrm{Hz}, \mathrm{SiH}), 7.30-7.38$ (m, Ph), $7.53(\mathrm{~d}, J=7.5 \mathrm{~Hz}, \mathrm{Ph})$; ${ }^{13} \mathrm{C}$ NMR ( $\delta$ in $\left.\mathrm{CDCl}_{3}\right) 8.49\left(\mathrm{CH}_{2} \mathrm{Si}\right), 25.48\left(\mathrm{OCH}_{2} \underline{\mathrm{CH}}_{2}\right)$, 30.72, 35.40, 40.61, 45.38 (Ad $\mathrm{CH}$ and $\left.\mathrm{CH}_{2}\right), 62.55$ $\left(\mathrm{OCH}_{2} \mathrm{CH}_{2}\right), 74.10$ (Ad q-C), 127.94, 129.51 (Ph CH), 134.35 ( $\mathrm{Ph}$ ipso $\mathrm{C}), 135.13(\mathrm{Ph} \mathrm{CH})$; Anal. Calcd for $\mathrm{C}_{40} \mathrm{H}_{48} \mathrm{O}_{2} \mathrm{Si}_{2}$ : C, 77.87; H, 7.84. Found: C, 77.60; H, 8.00.

\section{Hydrosilylation Polymerization}

A solution of $0.46 \mathrm{~g}(0.71 \mathrm{mmol})$ of $1 \mathrm{a}, 0.090 \mathrm{~g}(0.71 \mathrm{mmol})$ of 1,4-diethynylbenzene, $1.7 \mathrm{mg} \quad(0.0018 \mathrm{mmol})$ of $\mathrm{RhCl}\left(\mathrm{PPh}_{3}\right)_{3}$ in $2 \mathrm{~mL}$ of toluene was stirred at $70^{\circ} \mathrm{C}$ for $24 \mathrm{~h}$. The resulting mixture was passed through a short silica gel column eluting with toluene to remove the catalyst. After evaporation of the solvent, the residue was reprecipitated from chloroform-methanol to give $0.26 \mathrm{~g}(47 \%)$ of the hydrosilylated polymer (2a) as light yellow oil: ${ }^{1} \mathrm{H} \mathrm{NMR} \mathrm{(} \delta$ in $\mathrm{CDCl}_{3}$ ) 0.44-0.65 (m, $\left.\quad \mathrm{SiCH}_{2}\left(\mathrm{CH}_{2}\right)_{4} \mathrm{CH}_{3}\right), \quad 0.86 \quad(\mathrm{t}, \quad J=7.0 \mathrm{~Hz}$, $\left.\mathrm{SiCH}_{2}\left(\mathrm{CH}_{2}\right)_{4} \underline{\mathrm{CH}}_{3}\right), \quad 1.21-1.31 \quad\left(\mathrm{~m}, \quad \mathrm{SiCH}_{2}\left(\underline{\mathrm{CH}}_{2}\right)_{4} \mathrm{CH}_{3}\right.$ and $\mathrm{O}\left(\mathrm{CH}_{2}\right)_{2} \mathrm{CH}_{2} \mathrm{Si}$ ), $1.47-1.76$ (m, Ad and $\mathrm{OCH}_{2} \underline{\mathrm{CH}}_{2} \mathrm{CH}_{2} \mathrm{Si}$ ),

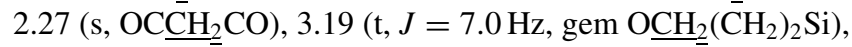
$3.34\left(\mathrm{t}, J=7.0 \mathrm{~Hz}\right.$, trans $\left.\mathrm{OCH}_{2}\left(\mathrm{CH}_{2}\right)_{2} \mathrm{Si}\right), 5.76(\mathrm{~d}, J=2.6 \mathrm{~Hz}$, $\left.\mathrm{C}=\mathrm{CH}_{2}\right), 6.11\left(\mathrm{~d}, J=2.6 \mathrm{~Hz}, \mathrm{C}=\mathrm{CH}_{2}\right), 6.70(\mathrm{~d}, J=19.1 \mathrm{~Hz}$, $\mathrm{CH}=\mathrm{CH}), 6.92(\mathrm{~d}, J=19.1 \mathrm{~Hz}, \mathrm{CH}=\mathrm{CH}), 7.43-7.32 \quad(\mathrm{~m}$, benzene ring $\mathrm{H}) ;{ }^{13} \mathrm{C} \mathrm{NMR}\left(\delta\right.$ in $\left.\mathrm{CDCl}_{3}\right) \quad 7.68$ (gem $\mathrm{O}\left(\mathrm{CH}_{2}\right)_{2} \underline{\mathrm{CH}}_{2} \mathrm{Si}$ ), 7.74 (trans $\mathrm{O}\left(\mathrm{CH}_{2}\right)_{2} \underline{\mathrm{CH}}_{2} \mathrm{Si}$ ), 11.02, 13.94, 22.39, 23.61 (Hex), 27.56 (gem $\mathrm{OCH}_{2} \underline{\mathrm{CH}}_{2}{ }^{\mathrm{C}} \mathrm{H}_{2} \mathrm{Si}$ ), 27.62 (trans $\mathrm{OCH}_{2} \mathrm{CH}_{2} \mathrm{CH}_{2} \mathrm{Si}$ ), 29.30 (Ad $\mathrm{CH}$ and $\mathrm{CH}_{2}$ ), 31.37, 33.08 (Hex), 35.41, 40.35, 45.55 ( $\mathrm{Ad} \mathrm{CH}$ and $\mathrm{CH}_{2}$ ), 67.18 (gem $\mathrm{OCH}_{2}\left(\mathrm{CH}_{2}\right)_{2} \mathrm{Si}$ ), 67.21 (trans $\underline{\mathrm{OCH}}_{2}\left(\mathrm{CH}_{2}\right)_{2} \mathrm{Si}$ ), 74.46 (Ad q-C), 118.07, 123.00, 126.04 (benzene ring $\mathrm{CH}, \mathrm{CH}=\mathrm{CH}$ and $\left.\mathrm{C}=\underline{\mathrm{CH}}_{2}\right), 131.95$ (benzene ring ipso $\left.\mathrm{C}\right), 137.97\left(\underline{\mathrm{C}}=\mathrm{CH}_{2}\right)$, $147.44(\mathrm{CH}=\mathrm{CH})$. In the NMR data, gem and trans indicate the signals of $\alpha$ - and $\beta$-silylated units, respectively. The ratio of $\beta$ silylation $/ \alpha$-silylation units was determined to be $88 / 12$ by the integration of the ${ }^{1} \mathrm{H}$ NMR signals.

Other hydrosilylated polymers were obtained in a manner similar to that above. Data for polymer $\mathbf{2 b}$ obtained from hydrosilylation of 1,4-diethynylbenzene with $\mathbf{1 b}$, followed by reprecipitation from chloroform-ethanol: yellow solid; ${ }^{1} \mathrm{H}$ NMR $\left(\delta\right.$ in $\left.\mathrm{CDCl}_{3}\right)$ 1.23-1.16 (m, $\left.\mathrm{CH}_{2} \mathrm{Si}\right), 1.84-1.44(\mathrm{~m}$, Ad and $\left.\mathrm{OCH}_{2} \underline{\mathrm{CH}}_{2}\right), 2.24\left(\mathrm{~s}, \mathrm{OCCH}_{2} \mathrm{CO}\right), 3.24(\mathrm{t}, J=7.0 \mathrm{~Hz}$, gem $\left.\mathrm{OCH}_{2} \mathrm{CH}_{2}\right), 3.36\left(\mathrm{t}, J=6.7 \mathrm{~Hz}\right.$, trans $\left.\mathrm{OCH}_{2} \mathrm{CH}_{2}\right), 5.68(\mathrm{~d}$, $\left.J=2.1 \mathrm{~Hz}, \mathrm{C}=\mathrm{CH}_{2}\right), 6.17\left(\mathrm{~d}, J=2.1 \mathrm{~Hz}, \mathrm{C}=\mathrm{CH}_{2}\right), 6.70(\mathrm{~d}$, $J=19.0 \mathrm{~Hz}, \mathrm{CH}=\mathrm{CH}), 6.91(\mathrm{~d}, J=19.0 \mathrm{~Hz}, \mathrm{CH}=\mathrm{CH}), 7.31-$ 7.56 (m, benzene ring $\mathrm{H}$ ); ${ }^{13} \mathrm{C} \mathrm{NMR}\left(\delta\right.$ in $\left.\mathrm{CDCl}_{3}\right) 9.43$ (trans
$\mathrm{CH}_{2} \mathrm{Si}$ ), 9.50 (trans $\mathrm{CH}_{2} \mathrm{Si}$ ), $25.01\left(\right.$ gem $\mathrm{OCH}_{2} \mathrm{CH}_{2}$ ), 25.06 (trans $\left.\mathrm{OCH}_{2} \underline{\mathrm{CH}}_{2}\right), 30.73,35.41,40.66,45.43(\mathrm{Ad} \mathrm{CH}$ and $\left.\mathrm{CH}_{2}\right), 62.98\left(\mathrm{gem} \mathrm{OCH}{ }_{2} \mathrm{CH}_{2}, 63.05\right.$ (trans $\left.\mathrm{OCH}_{2} \mathrm{CH}_{2}\right), 74.09$ (Ad q-C), 122.82, 123.87, 126.81, 127.85, 129.35, 134.16, 135.29, 135.55 (benzene ring $\mathrm{C}, \mathrm{CH}=\mathrm{CH}$, and $\mathrm{C}=\mathrm{CH}_{2}$ ), $137.98\left(\underline{\mathrm{C}}=\mathrm{CH}_{2}\right), 147.47(\mathrm{CH}=\mathrm{CH})$. The ratio of $\beta$-silylation/ $\alpha$-silylation units was determined to be $77 / 23$ by the integration of ${ }^{1} \mathrm{H}$ NMR siganals. Polymer $2 \mathbf{b}^{\prime}$ prepared by Ptcatalyzed hydrosilylation gave essentially the same NMR spectra as those above, except for the slightly higher $\beta$ silylation/ $\alpha$-silylation ratio of $81 / 19$.

Data for polymer 2c obtained by hydrosilylation of 1,4diethynylbenzene with 1c, followed by reprecipitation from THF-hexane: yellow solid; ${ }^{1} \mathrm{H}$ NMR $\left(\delta\right.$ in $\left.\mathrm{CDCl}_{3}\right) 0.29$ (br, $\mathrm{MeSiO}), 0.48(\mathrm{MeSiCH}=\mathrm{CH}), 0.54\left(\mathrm{br}, \underline{\mathrm{MeSiC}}=\mathrm{CH}_{2}\right), 1.26$ $2.17(\mathrm{~m}, \mathrm{Ad}), 5.68-6.09\left(\mathrm{~m}, \mathrm{H}_{2} \mathrm{C}=\right) 6.53(\mathrm{br} \mathrm{d}, J=19.0 \mathrm{~Hz}$, $\mathrm{CH}=\mathrm{CH}), 6.93(\mathrm{br} \mathrm{d}, J=19.0 \mathrm{~Hz}, \mathrm{CH}=\mathrm{CH}), 7.16-7.44,7.50$ 7.66 (br m, benzene ring $\mathrm{H}$ ); ${ }^{13} \mathrm{C} \mathrm{NMR}\left(\delta\right.$ in $\left.\mathrm{CDCl}_{3}\right) 0.12$, (SiMe), 25.60, 31.29, 34.62, 43.70, 43.90, 44.23, 44.45, 44.71, 54.18, 54.38, 67.97, 68.04 (Ad CH and $\mathrm{CH}_{2}$ ), 74.27 (Ad q-C), 126.46, 126.88, 127.49, 127.68, 127.80, 127.95, 129.59, 133.68, 133.91 (benzene ring $\mathrm{C}$ ). The ratio of $\mathrm{CH}=\mathrm{CHSiPhMeO} /$ $\mathrm{CH}_{2}=\mathrm{CSiPhMeO} / \mathrm{OSiPhMeO}$ units in the backbone was determined to be $14 / 72 / 14$ by the integration of the ${ }^{1} \mathrm{H}$ NMR signals.

Data for polymer $\mathbf{3 b}$ obtained from hydrosilylation of bis(allyloxy)adamantane with $\mathbf{1 b}$, followed by reprecipitation from chloroform-ethanol: yellow solid; ${ }^{1} \mathrm{H}$ NMR $\left(\delta\right.$ in $\left.\mathrm{CDCl}_{3}\right)$ 1.04-1.254 (m, O $\left.\left(\mathrm{CH}_{2}\right)_{2} \underline{\mathrm{CH}}_{2} \mathrm{Si}\right), 1.44-1.66$ (m, Ad and $\mathrm{OCH}_{2} \mathrm{CH}_{2} \mathrm{CH}_{2} \mathrm{Si}$ ), 2.24 (s, Ad $\mathrm{OCCH}_{2} \mathrm{CO}$ ), 3.31 (t, $J=6.7$ $\left.\mathrm{Hz}, \mathrm{OCH}_{2}\right), 7.58-7.32(\mathrm{~m}$, benzene ring $\mathrm{H}) ;{ }^{13} \mathrm{C} \mathrm{NMR}(\delta$ in $\left.\mathrm{CDCl}_{3}\right) 8.55\left(\mathrm{CH}_{2} \mathrm{Si}\right), 24.78\left(\mathrm{OCH}_{2} \mathrm{CH}_{2}\right), 30.70,35.37,40.61$, 45.37 (Ad $\mathrm{CH}$ and $\mathrm{CH}_{2}$ ), $63.18\left(\mathrm{OCH}_{2} \mathrm{CH}_{2}\right), 74.08$ (Ad q-C), 127.75, 129.12, 134.89 (benzene ring $\mathrm{C}$ ), 135.90 (benzene ring ipso C).

\section{Cross-linking Reactions of Poly[(dimethylsiloxane)-co- (methylvinylsiloxane)] (4) with 1c}

A solution of $1.29 \mathrm{~g}$ of $4,65 \mathrm{mg}$ of $1 \mathrm{c}$, and $23 \mathrm{mg}$ of $\mathrm{RhCl}\left(\mathrm{PPh}_{3}\right)_{3}$ in $10 \mathrm{~mL}$ of toluene was stirred at $80^{\circ} \mathrm{C}$ for $10 \mathrm{~h}$. To this was added approximately $200 \mathrm{mg}$ of triazinetrithiol (Sankyo Kasei Co. Ltd.) and the mixture was stirred for $30 \mathrm{~min}$ then was filtered to remove the catalyst. The solvent was evaporated to give $746 \mathrm{mg}$ ( $58 \%$ yield) of the cross-linked polymer (5) as viscous oil: ${ }^{1} \mathrm{H}$ NMR $\left(\delta\right.$ in $\left.\mathrm{CDCl}_{3}\right) 0.09$ (s, $\mathrm{MeSi}$ ), 1.42-1.85 (m, Ad), 2.30 (s, $\mathrm{OCCH}_{2} \mathrm{CO}$ ), 5.73-6.20 (m, vinyl), 7.14-7.69 (m, Ph). Removal of the catalyst is essential to obtain soluble cross-linked products. Skipping this process resulted in the formation of only insoluble substances.

Other cross-linking reactions were carried out in a manner similar to that above. For Pt-catalyzed reactions, removal of the catalyst by using complexing reagent was not necessary.

\section{RESULTS AND DISCUSSION}

Hydrosilylation polymerization was performed as shown in 

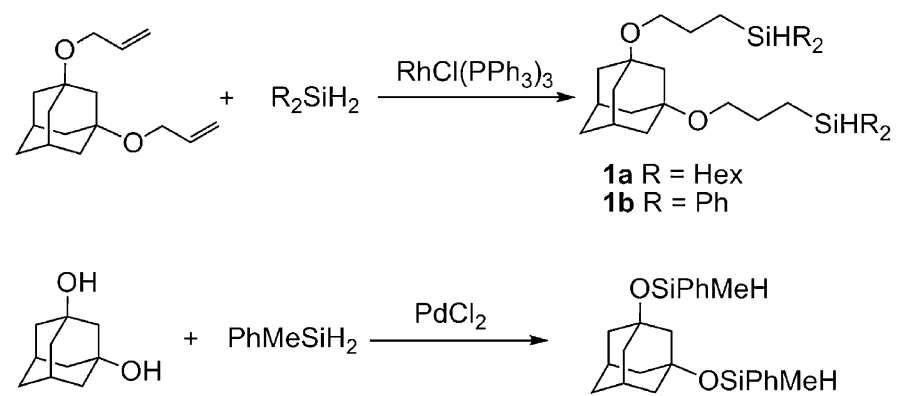

1c

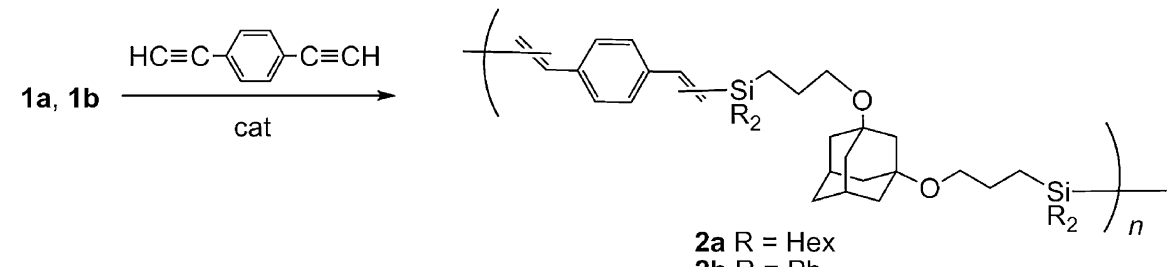

$2 \mathrm{~b} R=\mathrm{Ph}$
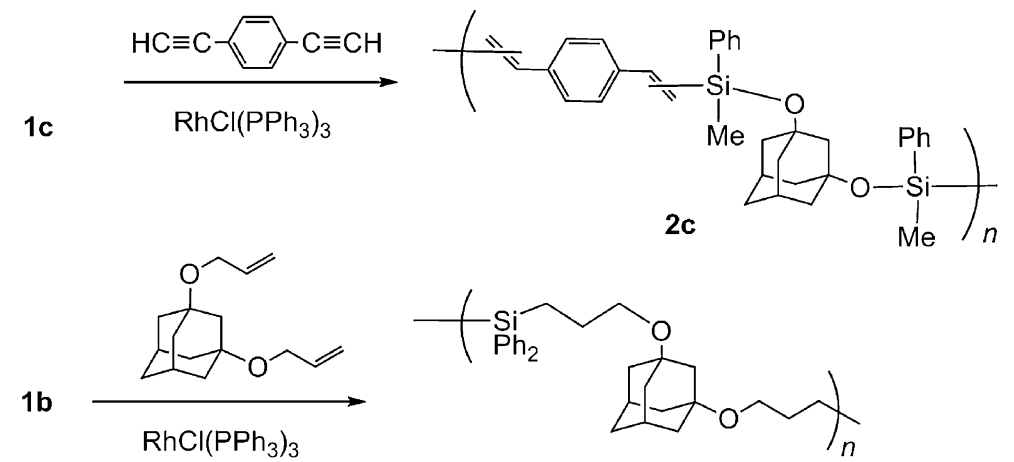

$3 b$

Scheme 2. Hydrosilylation polymerization leading to adamantane unit-containing linear polymers.

Table I. Hydrosilylation Polymerization

\begin{tabular}{cccccc}
\hline & & & & \multicolumn{2}{c}{$\mathrm{TGA}^{\mathrm{a}}$} \\
\cline { 6 - 7 } polymer & yield $/ \%^{\mathrm{b}}$ & $M_{\mathrm{n}}\left(M_{\mathrm{w}} / M_{\mathrm{n}}\right)^{\mathrm{C}}$ & $\mathrm{mp} /{ }^{\circ} \mathrm{C}$ & $T_{\mathrm{d}_{5}} /{ }^{\circ} \mathrm{C}$ & $T_{\mathrm{d}_{10}} /{ }^{\circ} \mathrm{C}$ \\
\hline 2a & 47 & $5400(1.8)$ & oil & & \\
2b & 68 & $4000(1.6)$ & $60-69$ & 341 & 384 \\
2b' & 79 & $4000(1.5)$ & $57-63$ & 265 & 359 \\
2c & 67 & $3900(3.5)$ & $81-89$ & 370 & 393 \\
3b & 59 & $3000(1.3)$ & $54-59$ & 340 & 371 \\
\hline
\end{tabular}

${ }^{a}$ In a nitrogen atmosphere, at the rate of $10^{\circ} \mathrm{C} / \mathrm{min} . T_{\mathrm{d}_{5}}$ and $T_{\mathrm{d}_{10}}$ are temperatures of $5 \%$ and $10 \%$ weight loss, respectively. ${ }^{b}$ After reprecipitation. ${ }^{\mathrm{C}}$ Determined by GPC, relative to polystyrene standards.

Scheme 2 and Table I. The reaction of diethynylbenzene with hydrosilane 1a gave polymer 2a as viscous light yellow oil, while with phenyl-substituted hydrosilanes $\mathbf{1 b}$ and $\mathbf{1 c}$, the corresponding hydrosilylated polymers $\mathbf{2 b}$ and $\mathbf{2 c}$ were obtained as yellow solids. These polymers are soluble in common organic solvents, such as chloroform, diethyl ether, THF, and toluene, but insoluble in methanol. The solubility decreased in the order of $\mathbf{2} \mathbf{a}>\mathbf{2 b}>\mathbf{2} \mathbf{c}$ and polymer $\mathbf{2 c}$ could be purified by reprecipitation even from hexane. Molecular weights of the polymers were determined by GPC to be $M_{\mathrm{n}}=3000-5400$, relative to polystyrene standards. The rather low molecular weights seem to be ascribed to low reactivity of the hydrosilanes due to the steric hindrance. Regioselectivity of the hydrosilylation was estimated by the ${ }^{1} \mathrm{H}$ NMR spectra of the polymers to be $\beta$-silylation $/ \alpha$-silylation $=88 / 12$ and $77 /$ 23 for $\mathbf{2 a}$ and $\mathbf{2 b}$, respectively. Using $\mathrm{H}_{2} \mathrm{PtCl}_{6} \cdot 6 \mathrm{H}_{2} \mathrm{O} / i \mathrm{PrOH}$ (Spier's catalyst) instead of $\mathrm{RhCl}\left(\mathrm{PPh}_{3}\right)_{3}$ for the reaction with 1b led to the formation of polymer $\mathbf{2} \mathbf{b}^{\prime}$ with a little higher degree of $\beta$-silylation $(\beta / \alpha=81 / 19)$. The ${ }^{1} \mathrm{H}$ NMR spectrum of polymer $2 \mathrm{c}$ revealed three broad MeSi signals at $0.29,0.48$, and $0.54 \mathrm{ppm}$ in a ratio of $14 / 72 / 14$ (Figure 1). Two at 0.48 and $0.54 \mathrm{ppm}$ were due to those of $\beta$ - and $\alpha$-silylated units, respectively, while one at $0.29 \mathrm{ppm}$ was assigned to siloxane units that would be formed by hydrolysis of terminal $\mathrm{Si}-\mathrm{H}$ units during the workup, by comparison with the literature data. ${ }^{8}$ The formation of the siloxane units is probably responsible for the higher polydispersity $\left(M_{\mathrm{w}} / M_{\mathrm{n}}\right)$ of $\mathbf{2} \mathbf{c}$ than those of $\mathbf{2 a}$ and $\mathbf{2} \mathbf{b}$. Hydrosilane 1b reacted also with bis(allyloxy)adamantane smoothly to give polymer $\mathbf{3 b}$ as a yellow solid. This polymerization proceeded regioselectively, and no $\alpha$-silylated units were found to be formed in the polymer backbone. These polymers are stable and standing them at room temperature in air under room light for several months led to no detectable changes in their spectra. 

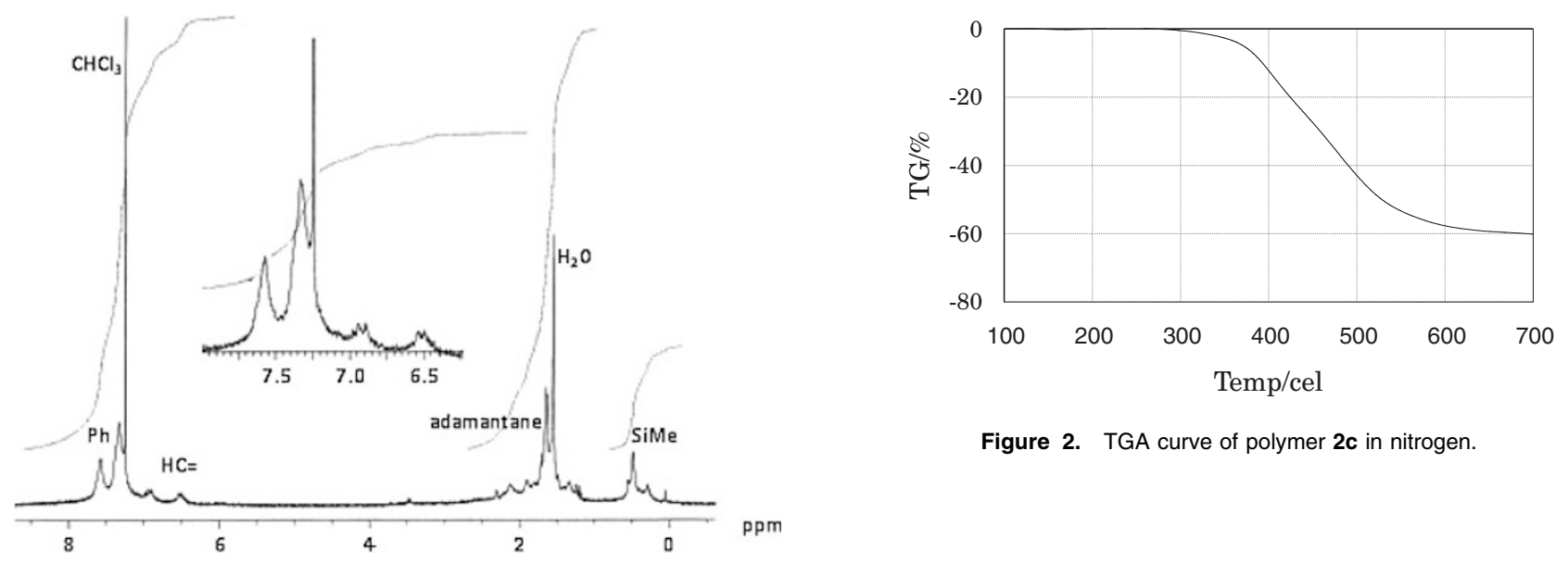

Figure 2. TGA curve of polymer $\mathbf{2 c}$ in nitrogen.

Figure 1. ${ }^{1} \mathrm{H}$ NMR spectrum of polymer $2 \mathrm{c}$ in $\mathrm{CDCl}_{3}$.

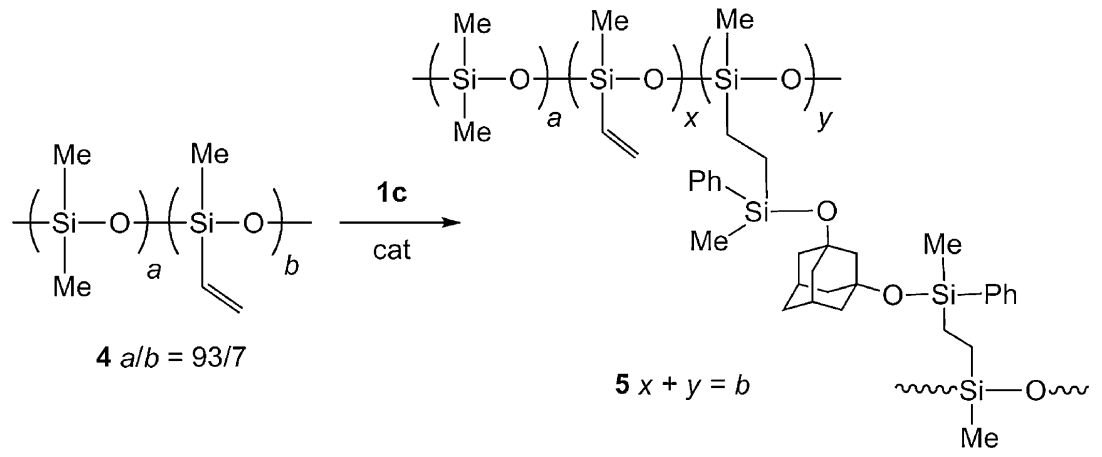

Scheme 3. Cross-linking hydrosilylation of a vinylsiloxane polymer.

Thermal properties of the phenyl-substituted polymers were examined by TGA in nitrogen, and $T_{\mathrm{d}_{5}}$ and $T_{\mathrm{d}_{10}}$ were noted as summarized in Table I. Of those, polymer $\mathbf{2 c}$ showed the highest $T_{\mathrm{d}_{5}}$ and $T_{\mathrm{d}_{10}}$ (Figure 2). They were lower than those reported for poly(adamantanediyl)s, ${ }^{2}$ adamantane-AN and MA copolymers, ${ }^{3}$ biadamantane unit-containing polyimides, ${ }^{4}$ and adamantane-siloxane polymers, ${ }^{7}$ but higher than or comparable to those of adamantane unit-containing polyimides (Scheme 1).

The introduction of propylene chains into the backbone suppresses the heat-resistance of polymers $\mathbf{2 b}$ and $\mathbf{3 c}$. However, it should be pointed out that polymer $\mathbf{2 b}$ showed a little inferior but almost comparable heat-resistance to that of $\mathbf{2 c}$ with respect to the $T_{\mathrm{d}_{10}}$ values. Interestingly, polymer $2 \mathbf{b}^{\prime}$ prepared by platinum-catalyzed hydrosilylation showed inferior resistance to $\mathbf{2 b}$. This is probably ascribed to the higher content of $\alpha$-silylated vinylene units $\left(\mathrm{H}_{2} \mathrm{C}=\mathrm{C}<\right)$ in polymer 2b. It is likely that sterically less hindered vinylene units are more reactive than ethenylene units $(-\mathrm{CH}=\mathrm{CH}-)$ towards thermal cross linking that would be involved in the TGA process to enhance the resistance. In fact, when polymer $2 \mathrm{c}$ was heated at $230{ }^{\circ} \mathrm{C}$ for $10 \mathrm{~min}$, the polymer became insoluble in organic solvents. Although no clear peaks were found in the differential thermal analysis (DTA), this is indicative of that some cross-linking reactions occurred to an extent. Attempted
Table II. Cross-linking of Polysiloxane $4^{\mathrm{a}}$ with 1c

\begin{tabular}{ccccc}
\hline 4/1c & catalyst $^{\mathrm{b}}$ & yield $/ \%$ & $\mathrm{x} / \mathrm{y}$ & $M_{\mathrm{n}}\left(M_{\mathrm{w}} / M_{\mathrm{n}}\right)$ \\
\hline $10 / 1$ & $\mathrm{~S}$ & 65 & $3.1 / 3.9$ & $38000(2.2)$ \\
$22 / 1$ & $\mathrm{~S}$ & 73 & $5.5 / 1.5$ & $24000(2.0)$ \\
$35 / 1$ & $\mathrm{~S}$ & 90 & $6.0 / 1.0$ & $21000(1.2)$ \\
$20 / 1$ & $\mathrm{~W}$ & 55 & $4.5 / 2.5$ & $41000(2.6)$ \\
\hline
\end{tabular}

${ }^{\mathrm{a}} M_{\mathrm{n}}=17000, M_{\mathrm{w}} / M_{\mathrm{n}}=1.4 .{ }^{\mathrm{b}} \mathrm{S}: \mathrm{H}_{2} \mathrm{PtCl}_{6} \cdot 6 \mathrm{H}_{2} \mathrm{O} / \mathrm{PrOH}, \mathrm{W}: \mathrm{RhCl}\left(\mathrm{PPh}_{3}\right)_{3}$.

measurements of glass transition temperature failed. The differential scanning calorimetry of the polymers always showed no clear phase-transition, except for melting.

Next, we studied cross-linking hydrosilylation of vinylsiloxane polymer $\mathbf{4}$ with $\mathbf{1 c}$ as shown in Scheme 3, and the results are summarized in Table II. The reactions proceeded smoothly to give cross-linked polymers $\mathbf{5}$ as viscous oil in good-high yields. No signals due to $\mathrm{Si}-\mathrm{H}$ groups were detected in the IR and ${ }^{1} \mathrm{H}$ NMR spectra of $\mathbf{5}$. Insoluble materials were always formed in these reactions, which were removed by filtration to decrease the yields. Heat-resistance of cross-linked polymers 5 was examined by TGA, to give $T_{\mathrm{d}_{5}}=330-440{ }^{\circ} \mathrm{C}$ and $T_{\mathrm{d}_{10}}=450-480^{\circ} \mathrm{C}$ in nitrogen, which were lower than those of the parent polymer $4\left(T_{\mathrm{d}_{5}}=480^{\circ} \mathrm{C}\right.$ and $T_{\mathrm{d}_{10}}=533$ 
$\left.{ }^{\circ} \mathrm{C}\right)$. This is probably due to the formation of small amounts of volatile by-products that were detected by GC analysis, under the reaction conditions.

In conclusion, we prepared adamantane unit-containing liner polymers by hydrosilylation of organic unsaturated compounds and bis(hydrosilyl)-substituted adamantanes. Unfortunately, their heat-resistance was not as high as we expected. Moreover, the UV spectra of the polymer films revealed tailing of the absorption band up to approximately $600 \mathrm{~nm}$, indicating that the present polymers may not be suitable for LED encapsulants in the present form and tuning the chemical structure is required. However, the high solubility in organic solvents and moderately high heat-resistance may allow us to use this type of the polymers as the electronic device materials, such as sealing materials and insulating films. The adamantanesiloxane skeleton may be also useful as the backbone for adhesion materials. We also demonstrated that bis(methylphenylsiloxy)adamantane is useful as a cross-linking reagent for unsaturated polymers by hydrosilylation reactions. Hydrosilylation polymerization would provide a new methodology to prepare adamantane unit-containing polymers and preparation of novel adamantane unit-containing polymers using it is now underway.

Acknowledgment. We thank Sankyo Kasei Co. Ltd. for gift of triazinetrithiol.
Received: May 25, 2009

Accepted: July 24, 2009

Published: September 4, 2009

\section{REFERENCES}

1. a) J. Jensen, M. Grimsley, and J. Mathias, J. Polym. Sci., Part A: Polym. Chem., 34, 397 (1996).

b) S. Kobayashi, T. Matsuzawa, S. Matsuoka, H. Tajima, and T. Ishizone, Macromolecules, 39, 5979 (2006).

c) T. Hashimoto, Y. Makino, M. Urushisaki, and T. Sakaguchi, J. Polym. Sci., Part A: Polym. Chem., 46, 1629 (2008).

2. a) T. Ishizone, S. Matsuoka, S. Sakai, W. Harada, and H. Tajima, Macromolecules, 37, 7069 (2004).

b) S. Matsuoka, N. Ogiwara, Y. Uehara, and T. Ishizone, Macromol. Symp., 240, 206 (2006).

c) M. Mugisawa, K. Ohnishi, and H. Sawada, Colloid Polym. Sci., 285, 737 (2007).

3. S. Matsuoka, N. Ogiwara, and T. Ishizone, J. Am. Chem. Soc., 128, 8708 (2006).

4. A. S. Mathews, I. Kim, and C.-S. Ha, J. Appl. Polym. Sci., 102, 3316 (2006).

5. M. Mugisawa, K. Ueno, K. Hamazaki, and H. Sawada, Macromol. Rapid Commun., 28, 733 (2007).

6. a) X. Su and X. Jing, J. Appl. Polym. Sci., 106, 737 (2007). b) T. Maehara, J. Takenaka, K. Tanaka, M. Yamaguchi, H. Yamamoto, and J. Ohshita, J. Appl. Polym. Sci., 112, 496 (2009).

7. J. Ohshita, K. Hino, K. Inata, A. Kunai, and T. Maehara, Polymer, 48, 4301 (2007).

8. E. A. Williams, "The Chemistry of Organic Silicon Compounds," S. Patai and Z. Rappoport, Ed., Willey, 1989, Chapter 8. 